\title{
The Role of Transformational Leadership and Effective Communication on the Implementation of Patient Safety With Trust as Mediation
}

\author{
Vivi Silvia ${ }^{1}$, Rokiah Kusumapradja ${ }^{2}$, Idrus Jus'at ${ }^{3}$
}

${ }^{1}$ Corespondece Author: viviana.silvia@ymail.com

1,2,3 Esa Unggul University, Jl. Arjuna Utara No.9, RT.1/RW.2, Duri Kepa, Kec. Kb. Jeruk, Kota Jakarta Barat, Daerah Khusus Ibukota Jakarta 11510

\begin{tabular}{l}
\hline I N D E X I N G \\
\hline Keywords: \\
Patient Safety; \\
Transformational \\
Leadership; \\
Effective \\
Communication; \\
Trust;
\end{tabular}

Kata kunci:

Keselamatan Pasien;

Kepemimpinan

Transformasional;

Komunikasi Efektif;

Kepercayaan;

\begin{abstract}
A B S T R AC T
Patient safety has become a global issue in the field of health service including hospital. Implementation of patient safety in the hospital requires the involvement of leadership, effective communication and patient's trust. At X Hospital Jakarta, the root case that frequently occurs on patient safety incident is communication matter. This has an impact on the reoccurrence of patient safety incident. This research aims to analyze the influence of transformational leadership and effective communication towards the implementation of patient safety by trust as mediation. The method of this research is causal associative with quantitative approach. There are 37 nurses as samples counted with G-Power Statistics application. The technique of collecting data uses primary data questionnaires and is processed by path analysis. The result shows that there is a great influence on transformational leadership towards trust. Therefore, in implementing patient safety in hospital, it needs program development on transformational leadership; controlling, and evaluating the implementation of effective communication; and improving nursing care as a form of professional nursing practice to create and to maintain patient's trust towards nurse.
\end{abstract}

\begin{abstract}
Keselamatan pasien telah menjadi isu global dalam bidang pelayanan kesehatan termasuk rumah sakit. Implementasi keselamatan pasien di rumah sakit memerlukan keterlibatan pimpinan, komunikasi efektif serta kepercayaan pasien. Di Rumah Sakit X Jakarta, akar masalah insiden keselamatan pasien tersering adalah komunikasi. Hal ini berdampak pada terjadinya insiden keselamatan pasien bahkan terulang kembali. Penelitian ini bertujuan menganalisis pengaruh kepemimpinan transformasional dan komunikasi efektif terhadap implementasi keselamatan pasien dengan kepercayaan sebagai mediasi. Metode penelitian yang digunakan adalah asosiatif kausal dengan pendekatan kuantitatif. Sejumlah 37 perawat sebagai sampel dihitung menggunakan aplikasi G-Power Statistik. Teknik pengumpulan data menggunakan data primer kuesioner dan diolah dengan analisis jalur. Hasil yang diperoleh terdapat pengaruh yang besar pada kepemimpinan transformasional terhadap kepercayaan. Hasil penelitian ini menunjukkan dalam mengimplementasikan keselamatan pasien di rumah sakit perlu adanya pengembangan program kepemimpinan transformasional, pengawasan dan evaluasi penerapan komunikasi efektif serta peningkatkan asuhan keperawatan sebagai bentuk praktik keperawatan profesional untuk menciptakan dan mempertahankan kepercayaan pasien terhadap perawat.
\end{abstract}

(C) 2021 JMMR. All rights reserved

Article history: Received 2020-11-16; Revised 2020-12-22; Accepted 2021-06-11

\section{INTRODUCTION}

Patient safety has become a global issue in the health service sector, including in hospital. Patient safety is an attempt to reduce the risk of unexpected injury in health care service until minimum value being accepted. This acceptable minimum value determined by current knowledge, possessed facilities, available resources, and carried out procedures must be more valuable than without other handling or procedures (Panesar et al., 2014). 
According to WHO data in 2017, research on adverse events in 26 low and middleincome countries, the frequency of adverse events is around $8 \%$, where $83 \%$ of these adverse events can be prevented and with a mortality rate of around $30 \%$. The estimated number of hospitalization in the world annually is 421 million, where approximately 42.7 million patients experiencing adverse events. Meginniss et al., (2012) declares that more than 40,000 patient safety incidents ocur in England everyday. Whereas according to the KKP-RS in 2011, the Patient Safety Incident in Indonesia reported that cases of adverse events $(14.41 \%)$ and near miss (18.53\%) caused by processes or clinical procedures $(9.26 \%)$, medication $(9.26 \%)$, and patients fell (5.15\%). Furthermore, the World Health Organization in 2016 revealed a surprising fact which stated that one of ten patients in developing countries, including Indonesia, had injury while having medical treatment in hospital.

In previous research, conducted by Merrill (2015) proves that transformational leadership styles has direct contribution to patient safety. Transformational leadership is the ability of a leader to change the condition of workplace, work motivation, work patterns, and work values that are perceived by subordinates so that they are able to optimize performance in order to achieve organization goals Bass (1985). Transformational leadership creates positive change which is valuable to the followers. This kind of leader focuses on influencing others to help, to look after, to encourage and to harmonize each other, and takes care organization comprehensively (Paracha et al., 2012). Furthermore, Izumi et al., (2017) states that the ability to communicate has an effect on improving patient safety culture. Good communication can improve patient's trust and safety as well.

A good communication means effective communication where there is exchanging information, idea, feeling which results change on attitude so that a good relationship between the message giver and the message recipient can be managed. The measurement of effectiveness of a communication process can be seen from the achievement of the message sender's goals. The messages the recipient perceives should be corresponding with sender's intention. The message delivery is affected by the backgrounds of a communicator (Berlo, 1960). The communication process held by nurses and patients must be based on a trusting relationship so that the nurses are truly able to convey the message properly, easily understood and can change the patient's attitude pattern regarding the meaning, ideas or opinion that will and have been conveyed (Pieter, 2017).

Furthermore, Ahmadpour et al., (2019) also stated that trust also had direct contribution towards the implementation of patient safety. A similar research was conducted by Auer et al., (2014) in order to accomplish and to cultivate trust among hospital leaders, including nurses. It is necessary to increase the priority given to patient safety and to have a genuine and sustainable interest in creating a patient safety culture. Mayer et al. (1995) defines trust as a person's willingness to be vulnerable to the actions of other people based on the expectation that the others will take certain actions that are important to the trustor regardless of the ability to monitor or to control the other party. Being vulnerable means the willingness to take risks. Trust is a reflection of a person's hope, assumption or belief dealing with the possibility that a person's future action will be beneficial and will not destroy his interest.

Other research relavan by Zhu et al. (2013), state that transformational leadership has a positive effect on trust. These research highlight the importance of affective trust as a 
mechanism which translates transformational leadership into positive work outcomes for the organization. Garrett (2016) also state effective communication is a necessary component of a patient safety program, which enables all members of the interdisciplinary health care team to effectively manage their individual roles and responsibilities in the perioperative setting; set expectations for safe, high-reliability care; and measure and assess outcomes. To sustain a culture of safety, effective communication should be standardized, complete, clear, brief, and timely. A relavan research was conducted by Ree \& Wiig (2020), the results of his result concluded Transformational leadership has a significant impact on patient safety culture and work engagement in home care services. Employees' perceptions of job demand, available resources and engagement also affect patient safety culture.

Jakarta X Hospital is a type C hospital, which provides special services on orthopaedic surgery \& orthopaedic grammatology. In accordance with its motto "Your Healing Is Our Happiness", the hospital strives to provide the best service for patients from information services or in all ways to provide safe and comfortable services to all patients in the $\mathrm{X}$ Hospital. Attention towards safety as quality control group in X Hospital started in 2009. However, until now, patient safety incidents still occur. Quarterly, one patient safety incident may occur. The main cause of safety incidents is communication matter. In this case, the most vulnerable factor on communication is the mistake in giving verbal instructions. Besides that, the culture of learning from incidents has not been maximally implemented. This is marked by reoccurrence of patient safety incident.

The realization of patient safety in the hospital requires involvement of the leadership, good communication and builds trust with patients as well. Leader plays a vital role in the organization. Meanwhile in practice, medical workers especially nurses, contribute very much in creating patient safety through interaction and communication with patients. So, nurses are expected to be able to act individually and trusted by patients.

Some previous researches show that there is an effect between leadership and communication on the implementation of patient safety. However, there is no research that has analyzed how trust mediates the influence of transformational leadership and effective communication on the implementation of patient safety. Based on the background and phenomena in the hospital, the writer is motivated to complete previous researches by conducting research that analyzes the effect of transformational leadership and effective communication on the implementation of patient safety with trust as a mediator.

\section{RESEARCH METHOD}

The type of research used in this study is causal associative research with a quantitative approach. This study is intended to determine the relationship between two or more variables. With this research, it will be possible to build a theory that functions to explain, to predict and to control an indication. A causal relationship is a relationship that is causal in nature from one variable (independent) influencing another variable (dependent). The sample was calculated using the G-Power Statistics application. In this study, the number of samples used was 37 nurses. This amount was obtained by entering a correlation value of 0.4 , $\alpha$ err probe 0.05 , and power 0.8 which then calculated so that a total sample size of 37 was obtained. 


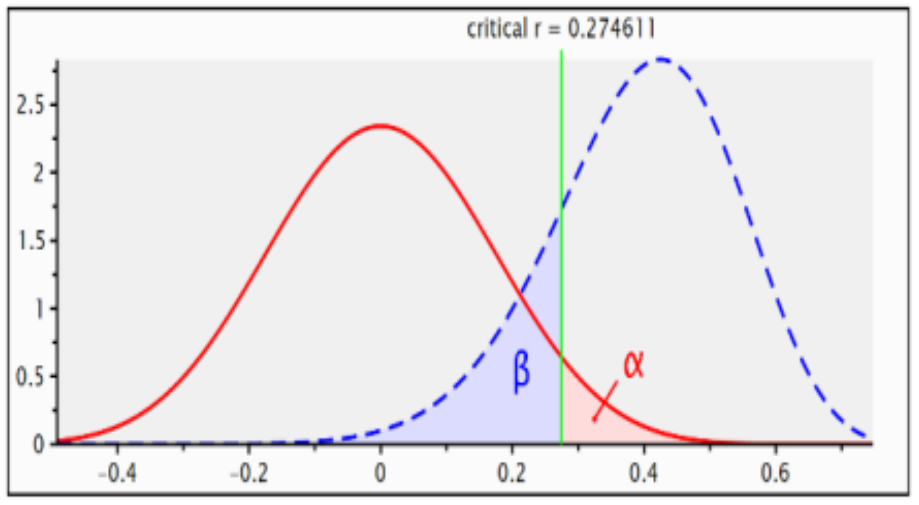

Figure.1 Minimal sample graph with $G$ * Power software

This research uses index analysis technique that describes the respondent's question items being asked. Respond index analysis on every variable aims to find a descriptive figure. 1 of the respondents in this research, especially the variables of this research used. Technique of collecting data in this research uses questionnaires. The scoring technique used in this research is a 5 maximum score and a 1 minimum by using Likert scale. To get the tendency of respondents' response to each variable, it will be based on the average score from the calculation of the Three Box Method. The categories for respondent perception assessment are as follows: low $=7,4-17,2$; medium $=17,3-27,1 ;$ high $=27,2-37$.

The dimension of implementation safety patient uses devices of Manchester Patient Safety Assessment Framework, consisting of: Sustainable improvement, Making Priority upon safety, non punitive respond towards error, Reporting errors and incidents, evaluating incidents, Learning and making change that has effect, Open Communication, Personnel management, Staff education and Teamwork. The dimensions of transformational leadership variable consist of ideal effect, inspirational motivation, intellectual stimulation, and individual consideration (Bass,1985). The dimensions of effective communication variables consist of (Robbin,2003): To the point, Assertive, Congenial, Clarity, Accuracy, Context, Flow, Culture. The dimensions of trust Variable consist of integrity, benevolence, competency, and predictability (Wiedenfels, 2009).

The validity test of the instrument items is carried out by using the SPSS (Statistical Package for Social Science) program. Researcher conducts validity test on 15 respondents and with a significant level of $5 \%$, so that the statement is said to be valid if the minimum result is 0.514 ( $\mathrm{r}$ table). Based on the results of SPSS, known that $\mathrm{r} \geq \mathrm{r}$ table, so that all instrument items are said to be valid or suitable for use. The results of the instrument reliability coefficient of the patient safety implementation is $\mathrm{rll}=0.919$, the transformational leadership instrument is $\mathrm{rll}=0.947$, the effective communication instrument is $\mathrm{rl}=0.929$ and the trust instrument is $\mathrm{rll}=0.850$. The results of the reliability test have a Cronbach Alpha more than 0.600 , which indicates that all instruments are assumed reliable or fulfill the requirements. This research has been received ethically with approval number : 0194-20.161/DPKEKEP/FINAL-EA/UEU/VII/2020. Method of data analysis in this research uses path analysis with AMOS software. The path analysis model based on concepts and theory are described as follows: 


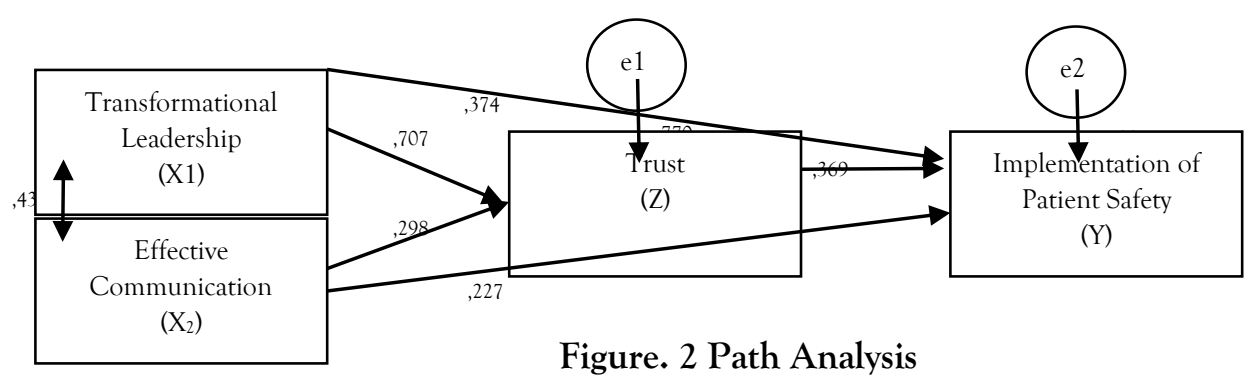

Based on figure.2 a structural equation is made, where $\mathrm{X}_{1}, \mathrm{X}_{2}$ showing exogenous variables while $\mathrm{Z}$ and $\mathrm{Y}$ are endogenous variables. The structural equation can be seen as follows:

$\mathrm{Z}=\mathrm{PZX}_{1}+\mathrm{PZX}_{2}+\varepsilon_{1}$

$\mathrm{Y}=\mathrm{PYX}_{1}+\mathrm{PYZ}+\mathrm{PYX}_{2}+\varepsilon_{2}$

Information:

$\mathrm{X}_{1}=$ Transformational Leadership

$X_{2}=$ Effective Communication

$\mathrm{Z}=$ Trust

$\mathrm{Y}=$ Implementation of Patient Safety

$\varepsilon_{12}=$ Error

The skewness value got from data analysys by using AMOS stands at at \pm 2.58 . Therefore it can be concluded that the data is on normal distributed. This test finds the determinant of the covariance matrix and the result is 54989.638 (positive result and more than 0.000 ). Eigen value 108,$931 ; 13,927 ; 7,380 ; 4,911$ is more than 0.01 , so there is no result, it can be concluded that there is no multicollinearity problem. Therefore, the test result is assumed to be reliable or trusted. The determination coefficient can be seen in the Squared Multiple Correlations table.

Table. 1 Square Multiple Correlations

\begin{tabular}{ll}
\hline & Estimate \\
\hline Trust & .770 \\
\hline Smplementation of Patient Safety & .733 \\
\hline Source: AMOS-path analysis output processed in 2020
\end{tabular}

From the results of the determination analysis, the effect of transformational leadership and effective communication on trust is $77 \%$, the effect of transformational leadership, effective communication and trust on the implementation of patient safety is $73.3 \%$, while the remaining $26.7 \%$ is affected by other factors of the research. The research hypothesis is formulated as follows:

H1. There is an effect of transformational leadership and effective communication on the implementation of patient safety with trust as mediation.

H2. There is an effect of transformational leadership on the implementation of patient safety.

H3. There is an effect of effective communication on the implementation of patient safety. 
H4. There is an effect of transformational leadership on trust.

H5. There is an effect of effective communication on trust

H6. There is an effect of trust on the implementation of patient safety.

\section{RESULT AND DISCUSSION}

\section{Result}

\section{Description of Respondent Characteristricts}

Most respondents (there are 20 respondents and it is $54 \%$ of the total) are $31-40$ years old. Meanwhile, the least number is 4 respondents (11\%) with age between 20-30 years. Based on gender, the female respondents are $30(81 \%)$ whereas male respondents are 7 (19 $\%)$. Most respondents have DII education, there are 32 (86\%) altogether. Meanwhile, respondents with S1 / professional education are 5 (14\%). Most respondents based on tenure, are $11-15$ years. The total numbers are 20 respondents $(54 \%)$.

\section{Descriptions of Respondents Answers}

Description of respondents answers is obtained from the total frequency of respondents in providing answers to every statement which measures the research variable. The results of the descriptive analysis recapitulation are presented as follows:

Table. 2 Descriptive Analysis Recapitulation

\begin{tabular}{llll}
\multicolumn{1}{c}{ Variable } & Index & Categories & Note \\
\hline Transformational Leadership & 29,00 & High & High motivation \\
\hline Effective Communication & 29,92 & High & Communicative \\
\hline Trust & 29,98 & High & Can be trusted \\
\hline Implementation of Patient Safety & 29,56 & High & High Patient Safety \\
\hline
\end{tabular}

Transformational leadership at X Hospital has motivated nurses to achieve common goals, but still lacks of inspirational motivation dealing with self-confidence. Although there are some nurses who are still fear to deliver information properly or unable to give information based on fact, most nurses have been communicative in giving information to patients. The nurses have also shown trusted attitude. To show trusted attitude towards patients, the nurses have had education competency corresponding with their tasks. There are few nurses who are still in process to make other people trust upon them. Whereas in implementing safety patients, the number of nurses needs to be increased. However, safety patient has been able to be implemented in hospital well.

\section{Simultant Test}

The first hypothesis in this research is that there is a significant effect of transformational leadership and effective communication on the implementation of patient safety with trust as mediation. The Chi-square result is 0.000 . Thus, it can be concluded that hypothesis 1 is accepted. 


\section{Partial Test}

In partial test, if the probability value $(\mathrm{P}) \leq 0.05$ then $\mathrm{Ho}$ is rejected (the research hypothesis is accepted). The results of processing by AMOS on the full model can be seen in table 3 below:

Table. 3 Regression Weight

\begin{tabular}{|c|c|c|c|c|c|c|c|}
\hline & & & Estimate & S.E & C.R & $\mathrm{P}$ & Label \\
\hline Transformational Leadership & $\rightarrow$ & $\begin{array}{l}\text { Implementation } \\
\text { of Patient Safety }\end{array}$ & 0,379 & 0,161 & 2,352 & 0,019 & accepted \\
\hline $\begin{array}{l}\text { Effective } \\
\text { Communication }\end{array}$ & $\rightarrow$ & $\begin{array}{l}\text { Implementation } \\
\text { of Patient Safety }\end{array}$ & 0,330 & 0,159 & 2,076 & 0,038 & accepted \\
\hline $\begin{array}{l}\text { Transformational } \\
\text { Leadership }\end{array}$ & $\rightarrow$ & Trust & 0,692 & 0,887 & 7,974 & 0,000 & accepted \\
\hline $\begin{array}{l}\text { Effective } \\
\text { Communication }\end{array}$ & $\rightarrow$ & Trust & 0,418 & 0,124 & 3,365 & 0,000 & accepted \\
\hline Trust & $\rightarrow$ & $\begin{array}{l}\text { Implementation } \\
\text { of Patient Safety }\end{array}$ & 0,382 & 0,186 & 2,052 & 0,040 & accepted \\
\hline
\end{tabular}

\section{Intervening Test}

Source: AMOS-path analysis output processed in 2020

The intervening test is calculated by considering the value of standardized direct effects and standardized indirect effects on the estimated parameters:

Table. 4 Standarized Direct Effects and Indirect Effects

\begin{tabular}{llcl} 
& & Direct effects & Indirect Effects \\
\hline $\begin{array}{l}\text { Transformational } \\
\text { Leadership }\end{array}$ & $\rightarrow$ Implementation of Patient Safety & 0,374 & 0,261 \\
\hline Effective Communication & $\rightarrow$ Implementation of Patient Safety & 0,227 & 0,110 \\
\hline
\end{tabular}

Source: AMOS-path analysis output processed in 2020

Based on table 4, it can be known that the direct effect of the transformational leadership variable on the implementation of patient safety is 0.374 . Meanwhile, theindirect effect of transformational leadership through trust on the implementation of patient safety is 0.261. So that Indirect Effects < Direct effects $(0.261<0.374)$. This means that there is no intervening, where trust does not lead to transformational leadership towards the implementation of patient safety. The direct effect given by the effective communication variable on the implementation of patient safety is 0.227 whereas the indirect effect of effective communication through trust on the implementation of patient safety is 0.110 . So Indirect Effects < Direct effects $(0.110<0.227)$. It means that there is no intervening, where trust does not lead to effective communication on the implementation of patient safety.

Thus, based on the above explanation, it can be concluded that the direct effect of transformational leadership and effective communication will be greater if compared to the indirect effect. Therefore, the implementation of patient safety can directly be influenced by transformational leadership and effective communication without going through trust. 


\section{Discussion}

\section{The Effect of Transformational Leadership and Effective Communication on the Implementation of Patient Safety with Trust as Mediation}

The result of simultaneous tests shows that there is effect of transformational leadership and effective communication on the implementation of patient safety as mediation. The results of the intervening test show the direct variable that has the greatest effect on the trust is the transformational leadership variable. The variable that has the greatest direct effect on the patient safety implementation variable is the transformational leadership variable as well.

Based on the respondent distribution analysis by using the three-box method, variable of patient safety implementation belongs to high category. $40.5 \%$ of nurses feel that the total amount of nurses at the X Jakarta hospital is insufficient. However, 97\% nurses do teamwork well in completing work even though the number of workers is assumed insufficient. Bass, (1985) states that transformational leadership is able to encourage and to motivate nurses in order to reaching goals in implementing patient safety in hospitals. Besides transformational leadership factor, task of every medical worker depends on the various factors, such as: effective communication. Through communication, there will be a relationship influencing one other, such as forming opinions, thoughts, appraisals, beliefs, attitude or certain behavior (Pieter, 2017). Besides, leadership and communication, Ahmadpour et al., (2019) also states that trust contributes to the implementation of patient safety.

The results of this research is relevant with the research of Auer et al. (2014)looking for the relationship between hospital management support for patient safety, trust of registered nurses in hospital management, and nurses' overall perception on patient safety by considering aspect of safety communication as a mediation variable. This research is also relevant with the research of Rezaei et al. (2012) which confirms that there is a significant relationship between serving leadership, organizational trust, leader trust and organizational communication.

\section{The Effect of Transformational Leadership on Patient Safety Implementation}

Based on the research results of the second hypothesis shows that there is a significant effect of transformational leadership on the implementation of patient safety. Through this influence, it can be interpreted that if transformational leadership increases, the implementation of patient safety at the $\mathrm{X}$ hospital will increase as well. Transformational leadership in improving the implementation of patient safety is greater on direct effect than through trust.

Based on the analysis of the distribution of respondents by using transformational leadership variables of the three-box method, belongs to high category. Transformational leadership at X Hospital has motivated nurses to achieve common goals. However, $27 \%$ of nurses feel that the leadership still lacks of inspirational motivation in fostering selfconfidence. This proves that self-confidence comes from internal individuals, but it can also be influenced by an environment. Therefore, the leader must be able to create an environment that fosters confidence in nurses. Leader plays an important role in motivating and encouraging followers to use their mind and potential to overcome job barriers, understand targeted goals and support organizational interests (Moye and Henkin, 2006). 
The result of this study is relevant with the research conducted by Merrill (2015) which proves that transformational leadership style is identified as positive contributor to patient safety and research conducted by Ree dan Wiig (2020) which shows that transformational leadership behavior has a significant impact on patient safety culture. Furthermore, this research is also relevant with the research results of Auer et al. (2014) which shows the importance of hospital leaders to campaign organizational learning at unit level to improve patient safety.

\section{The Effect of Effective Communication on Patient Safety Implementation}

Based on the research results of the third hypothesis, there is a significant effect of effective communication on the implementation of patient safety. Effective communication in improving the implementation of patient safety is greater on direct impact than through trust. Based on the analysis of the distribution of respondents by using the three box method of variable communication, effective communication belongs to the high category. Most nurses have already been communicative in conveying information to patients. However $27 \%$ of nurses in conveying information still have feelings of fear and are not yet firm to deliver truthful information based on facts or inaccuracy.

According to Mc. Crosky Larson and Knapp (2001), effective communication can be achieved by the highest degree of accuracy between communicators and communicants in the communication process. Communication is a process of social and interpersonal interaction in human life. The results of this research is relevant with the research conducted by Garrett (2016) which proves that failure in health service communication is a significant cause of sentinel events and is associated with morbidity and mortality of the patient, so that in order to maintainpatient safety ideally, communication and collaboration skill should be used. The results of this research is also relevant with the research by Izumi et al. (2017) which proves that by possessing good communication skill, it can improve patient safety.

\section{The Effect of Transformational Leadership on Trust}

Based on the results of the research, the fourth hypothesis shows that transformational leadership has a significant effect on trust. If transformational leadership increases, then trust will also increase. Transformational leadership has greater influence on trust comparing with effective communication. Based on the analysis of the distribution of respondents by using the three-box method, transformational leadership variables belong to high category. However, there are still $29.7 \%$ of nurses who feel that their leader has not provided direct interaction towards nurses in overcoming their difficulties and complaint.

Through the transformational leadership style, nurses will be directed, guided, taught, given examples and motivated to be able to do better than what they can. Thus it can increase their confidence and self-confidence (Bass, 1985). Therefore, it can be said that the existence of transformational leadership will change the attitude of nurses to be trustworthy, in words, actions and policies as well. The results of this research is relevant with the research conducted by Engelbrecht and Samuel (2019). Their research analyses the relationship between transformational leadership and organizational support, organizational justice and organizational trust. Then, this research is also relevant with the research conducted by Zhu 
et al., (2013) and Auer et al. (2014) which proves that transformational leadership has an effect on trust.

\section{The Effect of Effective Communication on Trust}

Based on the results of research on the fifth hypothesis, it shows that effective communication has a significant effect on trust. If there is an increase on effective communication, then trust will also increase. Based on the distribution analysis of respondents by using the three-box method, the average value of the effective communication variable has shown a high category. However, $21.6 \%$ of nurses have not been able to convey information clearly and easily understood, so that patients do not understand comprehensively the given information. This can be caused by communication handicap in the form of physical disorders (someone is talking), psychological (pre-existing thought) or semantics (misinterpret the meaning). Communication disorder is a common thing that can distort messages and prevent communicators in sending communication messages (Pieter, 2017).

Effective communication is a very important process in supporting the success of nursing care. Nurses who have good communication skills and abilities will easily foster patient trust. Wiedenfels (2009) states that in determining that nurses are experts and professionals who can help to solve patient problems need integrity, benevolence, competency and predictability from a trusted nurse hoping that the nurse is able to solve the problem appeared in a trusting relationship.

The results of this research is relevant with the research of Porumbescu, et.al (2012) which proves that interpersonal communication strategies are the most effective in maintaining vertical trust. Besides it, this result is also relevant with the research conducted by $\mathrm{Gu}$ et al. (2019) which proves that patients' perceptions of doctor's communication skills are a mediator in the relationship of contract service policies and trust building between patient and doctors. The advance of doctor's communication skills contributes to build trust between patient and doctor.

\section{The Effect of Trust on Patient Safety Implementation}

Based on the results of the research of the sixth hypothesis shows that trust has a significant effect on the implementation of patient safety. This means that if the trust value of nurses' increases, the implementation of patient safety at the $\mathrm{X}$ hospital will also improve. Based on the respondents' distribution analysis by using the three-box method, the trust variable belongs to the high category. The nurse has shown trustworthy attitude. To show the patient's trustworthiness, nurses have already had educational competencies that are appropriate for their work. However, $35.1 \%$ of nurses do not appear confident in creating other people's trust upon themselves. Nurses are less capable of displaying self-image so that they have not been able to fully create trustworthy nurse perception. The self-image indicator is a part of the predictability dimension in the trust variable. According to (Rempel, Holmes \& Zanna, 1985), predictability is an individual's belief that a person's behaviour can be predictable and consistent in certain achieved interactions. Patient trust is an essential element of successfully given health care. Trust towards medical staffs plays an important role in the patient's recovery or safety. 
The results of this research is relevant with the research of Ahmadpour et. al, (2019)that proves the presence of nurses is an important aspect of nursing care which improves the quality of nursing care and patient safety. The Research of Zineldin, (2015) concludes that trust on health workers greatly affects patient perceptions of safety. Patients trust health workers in providing care and safety. Meanwhile Birkhäuer et al., (2017) in their research reports that there will be more beneficial health behaviour, fewer symptoms and higher quality of life and more satisfied with treatment when they have higher trust in their health care professionals.

\section{CONCLUSION}

Transformational leadership has the greatest influence towards trust. In influencing the patient safety implementation, transformational leadership also has the greatest direct influence compared with indirect influence through trust. The transformational leadership role can be seen from the high value of the leadership's ability to influence and to motivate nurses. Transformational leadership is able to change the work environment, work motivation, work pattern and work values that are perceived by subordinates so that they are able to work optimally in achieving organizational goals. Based on the results of research and discussion in previous chapters as well as some of the results of previous research, several conclusions can be stated as follows: There is an effect of transformational leadership and effective communication on the implementation of patient safety. There is an effect of transformational leadership on the implementation of patient safety. There is an effect of effective communication on the implementation of patient safety. There is an effect of transformational leadership on trust. There is an effect of effective communication on trust.

There is an effect of trust on the implementation of patient safety. Based on the results of the research conclusions, several useful suggestions can be stated as follows: Leaders are expected to increase nurses' confidence by giving appreciation upon the achieved work and providing regular feedback. Involving the nurse in setting goals and evaluating the achievement of hospital goals. It is essential to hold routine meeting between leader and nurse to evaluate any obstacles and to find out the solutions. Hospital needs to provide training and skills development for nurse's communication skills, especially in the assertive aspect through assertive communication training and accuracy aspects through interpersonal communication training. It is hoped that the hospital had better support nurses in improving the trust value, especially in self-image by motivating nurses to appreciate and be proud of the nursing profession, rewarding nurses who do good work and creating a comfortable work environment so that nurses will work confidently and professionally to create a trustworthy attitude.

It is necessary to hold Emotional Spiritual Quotient (ESQ) training for hospital nurses to establish character by combining intellectual, emotional and spiritual intelligence in effort to improve integrity, benevolence, competency and predictability. Trying to add the number of nurses in hospital. In an effort to improve research results, the researcher suggests some points to the next researchers, as follows: Expanding and developing research theory so that the conclusions and parameters obtained can have a sharper level of generalization. Considering the possibility of other variables that influence the implementation of patient safety that they possibly have a much more significant level of relationship than the 
independent variables in this research, and expanding the study of the indicators of every variable through theory development efforts.

\section{ACKNOWLEDGMENT}

The writer would like to say thanks to Dr. RokiahKusumapradja, SKM, MHA and Mr. IdrusJus'at, M.Sc. $\mathrm{PhD}$ as an advisor. Furthermore, I also say thanks to Prof. Dr. EndangRuswanti, SE, MM, Dr. MF Arrozi SE., M. Si, Akt., CA and Dr. Rian Adi Pamungkas, M.N.S., P.H.Ns as examiners. Many thanks for the knowledge and time that have been given, and guidance, advice, and supervision as well during the completion of research result.

\section{REFERENCE}

Ahmadpour, B., Ghafourifard, M., \& Ghahramanian, A. (2019). Trust towards nurses who care for haemodialysis patients: a cross-sectional study. Scandinavian Journal of Caring Sciences, 4. https://doi.org/10.1111/scs.12809

Auer, C., Schwendimann, R., Koch, R., De Geest, S., \& Ausserhofer, D. (2014). How hospital leaders contribute to patient safety through the development of trust. Journal of $\begin{array}{lll}\text { Nursing } \quad \text { Administration, } & \text { 44(1), }\end{array}$ https://doi.org/10.1097/NNA.0000000000000017

Bass, B. M. (1985). Leadership and Performance Beyond Expectation. Free Press.

Birkhäuer, J., Gaab, J., Kossowsky, J., Hasler, S., Krummenacher, P., Werner, C., \& Gerger, H. (2017). Trust in the health care professional and health outcome: A meta-analysis. PLoS ONE, 12(2), 1-13. https://doi.org/10.1371/journal.pone.0170988

Engelbrecht, A., \& Samuel, O. M. (2019). The effect of transformational leadership on intention to quit through perceived organisational support, organisational justice and trust. South African Journal of Economic and Management Sciences, 22(1). https://doi.org/10.4102/sajems.v22i1.2338

Garrett, J. H. (2016). Effective Perioperative Communication to Enhance Patient Care. AORN Journal, 104(2), 111-120. https://doi.org/10.1016/j.aorn.2016.06.001

Gu, L., Deng, J., Xu, H., Zhang, S., Gao, M., Qu, Z., Zhang, W., \& Tian, D. (2019). The impact of contract service policy and doctor communication skills on rural patientdoctor trust relationship in the village clinics of three counties. BMC Health Services Research, 19(1), 1-9. https://doi.org/10.1186/s12913-019-3875-x

Izumi, S., Furusawa, Y., Bansho, M., \& Tonomura, I. (2017). Identification of communication skills that improve patient safety culture: analysis of a communication skills training program for university hospital staff. Japanese Journal of Comprehensive Rehabilitation Science, 8, 88-97. https://doi.org/10.11336/jjcrs.8.88

Meginniss, A., Damian, F., \& Falvo, F. (2012). Time out for patient safety. Journal of Emergency Nursing, 38(1), 51-53. https://doi.org/10.1016/j.jen.2011.04.007

Merrill, K. C. (2015). Leadership Style and Patient Safety: Implications for Nurse Managers. 
Journal of Nursing Administration, 45(6), 319-324. https://doi.org/10.1097/NNA.0000000000000207

Panesar, S., Carson-Stevens, A., Salvilla, S., \& Sheikh, A. (2014). Patient Safety and Healthcare Improvement at a Glance (1st ed.). WileyBlackwell. https://books.google.com/books?id=LQDeAwAAQBAJ\& pgis=1

Paracha, B. M. U., Qamar, A., Mirza, A., \& Waqas, H. (2012). “Impact of Leadership Style ( Transformational \& Transactional Leadership ) On Employee Performance \& Mediating Role of Job S .... "Impact of Leadership Style ( Transformational \& Transactional Leadership ) On Employee Performance \& Mediating Role of Jo. Global Journal of Management and Business Research, 12(4), 54-64.

Pieter, H. Z. (2017). Dasar-Dasar Komunikasi Bagi Perawat (1st ed.). Kencana.

Porumbescu, G., Park, J., \& Oomsels, P. (2012). Building trust: Communication and subordinate trust in public organizations. Transylvanian Review of Administrative Sciences, $38,158-179$.

Ree, E., \& Wiig, S. (2020). Linking transformational leadership, patient safety culture and work engagement in home care services. Nursing Open, 7(1), 256-264. https://doi.org/10.1002/nop2.386

Rezaei, M., Salehi, S., Shafiei, M., \& Sabet, S. (2012). Servant Leadership and Organizational Trust: the Mediating Effect of the Leader Trust and Organizational Communication. EMAJ: Emerging Markets Journal, 2(1), 70-78. https://doi.org/10.5195/emaj.2012.21

Zhu, W., Newman, A., Miao, Q., \& Hooke, A. (2013). Revisiting the mediating role of trust in transformational leadership effects: Do different types of trust make a difference? Leadership Quarterly, 24(1), 94-105. https://doi.org/10.1016/j.leaqua.2012.08.004

Zineldin, M. (2015). Determinants of patient safety, satisfaction and trust: With focus on physicians-nurses performance. Clinical Governance, 20(2), 82-90. https://doi.org/10.1108/CGIJ-12-2014-0038 